Shu Okamura • Kumiko Koyama • Yasuo Miyoshi •

Morito Monden • Motohisa Takami

\title{
Novel germline mutations of $h M S H 2$ in a patient with hereditary nonpolyposis colorectal cancer (HNPCC) and in a patient with six primary cancers
}

Received: November 13, 1997 / Accepted: January 14, 1998

\begin{abstract}
We screened for germline mutations of mismatch repair genes, $h M L H 1$ and $h M S H 2$, in five Japanese families carrying hereditary nonpolyposis colorectal cancer (HNPCC) and in a patient with multiple primary cancers. Screening the entire coding regions of both genes using polymerase chain reaction-single strand conformation polymorphism (PCR-SSCP) analysis, we found two novel germline mutations in $h M S H 2$. One was a 1-bp insertion in exon 12 , detected in a patient who had undergone surgery six times for independent tumors (four primary colorectal carcinomas, a small intestinal carcinoma, and an endometrial cancer). The other, in a second patient, was a missense mutation from CTT to TTT at codon 390 in exon 7 that resulted in substitution of phenylalanine for leucine. This conservative alteration was not found in any of 50 normal controls, but we cannot exclude the possibility that it may represent a rare polymorphism rather than a factor in the disease.
\end{abstract}

Key words Hereditary nonpolyposis colorectal cancer (HNPCC) · Mismatch repair genehMSH2 · Multiple primary cancers

\section{Introduction}

Hereditary nonpolyposis colorectal cancer (HNPCC), a common autosomal dominant cancer syndrome, is characterized by early onset of cancers in various tissues such as

S. Okamura $\cdot$ K. Koyama $(\bowtie) \cdot$ Y. Miyoshi

Division of Clinical Genetics, Department of Medical Genetics,

Biomedical Research Center, Osaka University Medical School,

2-2 Yamadaoka, Suita 565, Japan

Tel. +81-6-879-3381; Fax +81-6-879-3389

e-mail:kumiko@clgene.med.osaka-u.ac.jp

S. Okamura $\cdot$ M. Monden

Department of Surgery II, Osaka University Medical School, Suita, Japan

M. Takami

Department of Surgery, Toyonaka City Hospital, Toyonaka, Japan colorectum, uterus, stomach, biliary tract, urinary tract, and ovary (Lynch et al. 1993); many affected individuals are diagnosed with two or more primary cancers. HNPCC results from germline mutations in the human homologues of bacterial and yeast mismatch-repair genes; these include hMLH1 (Bronner et al. 1994 ; Papadopoulos et al. 1994), hMSH2 (Fishel et al. 1993; Leach et al. 1993), hPMS1, hPMS2 (Nicholaides et al. 1994), and GTBP (Akiyama et al. 1997; Miyaki et al. 1997). Although the proportion of HNPCC attributable to each of these genes remains unclear, defects of $h M L H 1$ and $h M S H 2$ are considered to be the most common causes; each accounts for $30 \%-40 \%$ of HNPCC families (Liu et al. 1994, 1996; Han et al. 1995). In this study, using polymerase chain reaction-single strand conformation polymorphism (PCR-SSCP) analysis we screened the $h M L H 1$ and $h M S H 2$ genes for mutations in five HNPCC families and in a patient with a history of six independent primary cancers.

\section{Materials and methods}

Patients. We obtained blood samples with informed consent from members of five families clinically defined as having HNPCC, and from one patient who had no family history of cancer as far as we could ascertain, but whose personal history included six independent primary cancers (four colorectal, one small intestinal, and one endometrial). Peripheral blood samples were obtained from up to three members of each of the families (including one or more affected individuals) and DNAs were extracted from these samples according to methods described elsewhere (Sato et al. 1990).

Polymerase chain reaction (PCR). For SSCP analysis, each exon of the $h M L H 1$ and $h M S H 2$ genes, along with flanking intronic sequences, was amplified from genomic DNA. The oligonucleotide primer sequences were described before (Han et al. 1995). Each of the 19 exons of $h M L H 1$ and the 16 exons of $h M S H 2$ was amplified in a total volume of $20 \mu \mathrm{l}$ 
containing $50 \mathrm{ng}$ genomic DNA, $2 \mu \mathrm{l}$ of $10 \times$ PCR buffer, 10 pmoles of each primer, $4.5 \mu \mathrm{M}$ of each dNTP, and 1 unit of Taq DNA polymerase, for 35 cycles at the annealing temperature calculated according to the composition of its primers, on the GeneAmp PCR system 9600 (Perkin Elmer Cetus, Norwalk, CT, USA).

Single strand conformation polymorphism (SSCP) analysis. Nonradioisotopic SSCP analysis was carried out as previously described (Oto et al. 1993). Mixtures containing $2 \mu \mathrm{l}$ of each PCR product and $2 \mu \mathrm{l}$ of a denaturing stop solution (95\% formamide, $10 \mathrm{mM}$ ethylenediaminetetraacetic acid (EDTA), $0.25 \%$ bromophenol blue, and $0.25 \%$ xylene cyanol) were heated to $80^{\circ} \mathrm{C}$ for $5 \mathrm{~min}$ and quenched on ice; $2 \mu \mathrm{l}$ of each denatured mixture was loaded on a $5 \%$ polyacrylamide gel containing $10 \%$ glycerol and electrophoresed for $16 \mathrm{~h}$ under running conditions of $400-500 \mathrm{~V}$ at $4^{\circ} \mathrm{C}$. After electrophoresis, the gels were stained with SYBR Green II (FMC BioProducts, San Jose, CA, USA) and visualized by means of a FMBIO II Multi-View fluorescent image analyzer (Takara, Otsu, Japan).

DNA Sequencing. Products that showed abnormal patterns on SSCP analyses were reamplified with Taq polymerase, subcloned into pBluescript II SK(-) vector (Stratagene, La Jolla, CA, USA), and sequenced using the T3 and T7 primers. The sequencing analyses for each product were performed using an Applied Biosystems model 377 DNA sequencer and the Perkin Elmer Dye Terminator Cycle Sequencing FS Ready Reaction Kit.

\section{Results and discussion}

We identified possibly disease-causative mutations of the $h M S H 2$ gene in two of the six individuals screened by PCRSSCP. One was a 1-bp insertion at codon 596 (AAT to AAAT) in exon 12, detected in the patient whose medical history included six primary cancers; this change led to a frameshift and a premature termination (Fig. 1). This patient, who had no family history of cancer clustering, had undergone surgery six times for removal of independent carcinomas; ascending colon cancer at age 37, transverse colon cancer at age 38 , rectal cancer at age 40 , ileal cancer at age 47, and sigmoid colon cancer and endometrial cancer at age 50. As no DNA samples were available from her parents, we do not know whether the mutation occurred de novo or was inherited. However, each offspring of the patient is likely to carry a $50 \%$ chance of being at high risk of cancer unless the mutation in this proband is chimeric and her germline cells do not contain the mutation.

In a second patient, another aberration was detected: a missense mutation involving a C (CTT) to T (TTT) transition at codon 390 (Leu to Phe) in exon 7 (Fig. 2). The same substitution was found in all of her three children, one of whom was found to have a colorectal cancer at the age of 20; the other two children, in their twenties, have so far had no tumors. Although this amino-acid substitution was a conservative change, it was not found in any of 50 normal controls. Hence, we think it may be responsible for HNPCC in this family, but we are unable to exclude the possibility that it represents a very rare polymorphism. To our knowledge, most mutations discovered so far in $h M S H 2$ have been deletions/insertions or nonsense alterations resulting in truncations of the predicted protein products; few missense mutations in this gene have been reported. However, most of the mutations described to date were revealed by in vitro transcription/translation reaction (IVTT) assays (Hall et al. 1994), and the link between translation-terminating mutations in $h M S H 2$ and carcinogenesis was clear (Luce et al. 1996). In the case reported here, the patient's family had a typical HNPCC pedigree. Since the same missense mutation was also detected in her two children, careful clinical surveillance is indicated for them even though neither has yet shown signs of cancer.

HNPCC is caused by mutations in genes encoding proteins that play significant roles in DNA mismatch-repair systems. It should be possible to improve clinical management through accurate presymptomatic diagnosis of carrier status among members of HNPCC families (Froggatt et al. 1995). However, molecular diagnosis remains difficult because (a) most HNPCC kindreds are unsuitable for genetic linkage studies that could indicate which gene needs to be examined; (b) most reported mutations have been unique to single families, so the mutation in each HNPCC family
Fig. 1 A Polymerase chain reaction - single strand conformation polymorphism (PCRSSCP) patterns in exon 12 of the $h M S H 2$ gene. A mutant band (arrow) is present in the patient $(P t)$. B Nucleotide sequences revealing a 1-bp insertion in exon 12 of $h M S H 2$. (i), normal allele; (ii), mutant allele of the patient. Both alleles were sequenced from single colonies

\section{A}

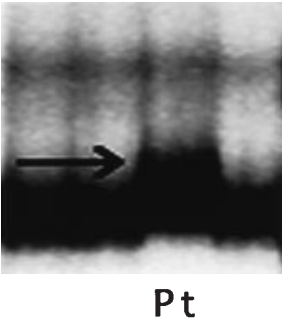

B

(i)

(complementary) ATC ATT GAG codon 597596595

ATCATTGAG

)

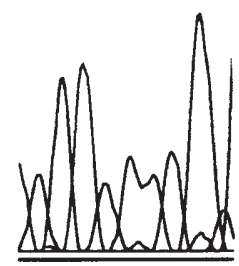

(ii)

(complementary) TCA TTT GAG codon 597596595

TCATTTG A G 230

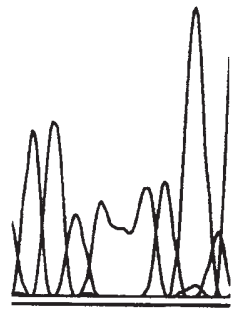


Fig. 2 A PCR-SSCP patterns in exon 7 of the $h M S H 2$ gene. Mutant bands (arrows) are present in the proband $(P)$ and her two asymptomatic children $(C 1$ and $C 2)$. B Nucleotide sequences revealing a C (CTT) to T (TTT) transition at codon 390 (Leu to Phe) in exon 7 of hMSH2. (i), normal allele; (ii), mutant allele of the patient. Both alleles were sequenced from single colonies
A

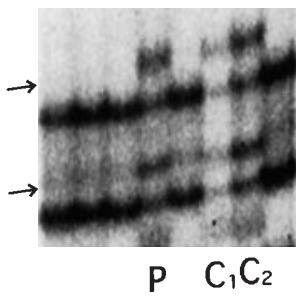

B

(i)

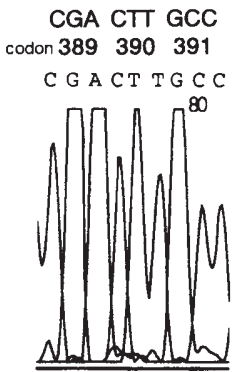

(ii)

CGA ITT GCC codon 389390391

C G A T T TG C C

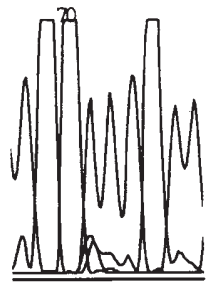

must be newly defined; (c) of the several techniques used to search for mutations, none has achieved both accuracy and simplicity; and (d) if several genes must be examined before a family's mutation is found, the expense will be prohibitive for most people.

\section{References}

Akiyama Y, Sato H, Yamada T, Nagasaki H, Tsuchiya A, Abe R, Yuasa Y (1997) Germ-line mutation of the $h M S H 6 / G T B P$ gene in an atypical hereditary nonpolyposis colorectal cancer kindred. Cancer Res 57: 3920-3923

Bronner CE, Baker SM, Morrison PT, Warren G, Smith LG, Lescoe MK, Kane M, Earabino C, Lipfold J, Lindblom A, Tannergard P, Bollag RJ, Godwin AR, Ward DC, Nordenskjold M, Fishel R, Kolodner R, Liskay RM (1994) Mutation in the DNA mismatch repair gene homologue $h M L H 1$ is associated with hereditary nonpolyposis colon cancer. Nature 368: 258-261

Fishel R, Lescoe MK, Rao MRS, Copeland NG, Jenkins NA, Garber J, Kane M, Kolodner R (1993) The human mutator gene homolog $M S H 2$ and its association with hereditary nonpolyposis colon cancer. Cell 75: 1027-1038

Froggatt NJ, Joyce JA, Davies R, Evans DGR, Ponder BAJ, Barton DE, Maher ER (1995) A frequent $h M S H 2$ mutation in hereditary non-polyposis colon cancer syndrome. Lancet 345: 727

Hall NR, Taylor GR, Finan PJ, Kolodner RD, Bodmer WF. Cottrell SE, Frayling I, Bishop DT (1994) Intron splice acceptor site sequence variation in the hereditary non-polyposis colorectal cancer gene $h M S H 2$. Eur J Cancer 30A: 1550-1552

Han H-J, Maruyama M, Baba S, Park J-G, Nakamura Y (1995) Genomic structure of human mismatch repair gene, $h M L H 1$, and its mutation analysis in patients with hereditary nonpolyposis colorectal cancer (HNPCC). Hum Mol Genet 4: 237-242

Leach FS, Nicholaides NC, Papadopoulos N, Liu B, Jen J, Parsons R, Peltomäki P, Sistonen P, Aaltonen LA, Nyström-Lahti M, Guan X-Y, Zhang J, Meltzer PS, Yu J-W, Kao F-T, Chen DJ, Carosaletti KM, Fournier REK, Todd S, Lewis T, Leach RJ, Naylor SL, Weissenbach J, Mecklin J-P, Järvinen H, Petersen GM, Hamilton
SR, Green J, Jass J, Watson P, Lynch HT, Trent JM, de la Chapelle A, Kinzler KW, Vogelstein B (1993) Mutations of a mut S homolog in hereditary nonpolyposis colorectal cancer. Cell 75: 1215-1225

Liu B, Parsons RE, Hamilton SR, Petersen GM, Lynch HT, Watson P, Marcowitz S, Willson JKV, Green J, de la Chapelle A, Kinzler KW, Vogelstein B (1994) hMSH2 mutations in hereditary nonpolyposis colorectal cancer kindreds. Cancer Res 54: 4590-4594

Liu B, Parsons R, Papadopoulos N, Nicholaides NC, Lynch HT, Watson P, Jass JR, Dunlop M, Wyllie A, Peltomäki P, de la Chapelle A, Hamilton SR, Vogelstein B, Kinzler KW (1996) Analysis of mismatch repair genes in hereditary non-polyposis colorectal cancer patients. Nat Med 2: 169-174

Luce MC, Binnie CG, Cayouette MC, Kam-Morgan LNW (1996) Identification of DNA mismatch repair gene mutations in hereditary nonpolyposis colon cancer patients. Int J Cancer 69: 50-52

Lynch HT, Smyrk TC, Watson P, Lanspa SJ, Lynch JF, Lynch PM, Cavalieri RJ, Boland R (1993) Genetics, natural history, tumor spectrum, and pathology of hereditary nonpolyposis colorectal cancer: an updated review. Gastroenterology 104: 1535-1549

Miyaki M, Konishi M, Tanaka K, Kikuchi-Yanoshita R, Muraoka M, Yasuno M, Igari T, Koike M, Chiba M, Mori T (1997) Germline mutation of MSH6 as the cause of hereditary nonpolyposis colorectal cancer. Nat Genet 17: 271-272

Nicholaides NC, Papadopoulos N, Liu B, Wei Y-F, Carter KC, Ruben SM, Rosen CA, Haseltine WA, Fleischmann RD, Fraser CM, Adams MD, Venter JC, Dunlop MG, Hamilton SR, Petersen GM, de la Chapelle A, Vogelstein B, Kinzler KW (1994) Mutations of two PMS homologues in hereditary nonpolyposis colon cancer. Nature 371: $75-80$

Oto M, Miyake S, Yuasa Y (1993) Optimization of nonradioisotopic single strand conformation polymorphism analysis with a conventional minislab gel electrophoresis apparatus. Anal Biochem 213: 19-22

Papadopoulos N, Nicholaides NC, Wei Y-F, Ruben SM, Carter KC, Rosen CA, Haseltine WA, Fleischmann RD, Fraser CM, Adams MD, Venter JC, Hamilton SR, Petersen GM, Watson P, Lynch HT, Peltomäki P, Mecklin J-P, de la Chapelle A, Kinzler KW, Vogelstein B (1994) Mutation of a mut L homolog in hereditary colon cancer. Science 263: 1625-1629

Sato T, Tanigami A, Yamakawa K, Akiyama F, Kasumi F, Sakamoto G, Nakamura Y (1990) Allelotype of breast cancer: cumulative allele losses promote tumor progression in primary breast cancer. Cancer Res 50: 7184-7189 